We investigated if serial domiciliary measures of spirometry were sensitive at detecting subtle effects of beta- 2 blockade associated with bisoprolol. This was a sub-study of NCT01656005 where domiciliary diary data were available on $\mathrm{n}=17$ patients with GOLD B/C COPD comprising domiciliary $\mathrm{FEV}_{1},(\mathrm{am} / \mathrm{pm})$, heart rate, oxygen saturation, salbutamol use, and global symptom score. Patients received a two week run in (baseline) on inhaled corticosteroid (ICS) and long acting beta-2 agonist (LABA): beclometasone/formoterol 100/6 $\mu \mathrm{g}, 2$ puffs BID. Thereafter they were placed on triple therapy with the addition of a long acting muscarinic receptor antagonist (LAMA) as Tiotropium $18 \mu \mathrm{g}$ OD, with concomitant weekly dose titration of bisoprolol as: $1.25 \mathrm{mg}-2.5 \mathrm{mg}-5 \mathrm{mg}$. After a further week of bisoprolol $5 \mathrm{mg}$, they were stepped back down to dual therapy (ICS/LABA) and continued this for one week. Mean age was 64 years, mean $\mathrm{FEV}_{1} 52 \%$ predicted, mean $\mathrm{FEV}_{1} / \mathrm{FVC}$ ratio of 0.46 , mean 50 pack year smoking history, and $7 \%$ mean $\mathrm{FEV}_{1}$ reversibility to salbutamol $400 \mu \mathrm{g}$. Compared to a baseline am $\mathrm{FEV}_{1}$ of $1.38 \mathrm{~L}(95 \% \mathrm{CI}$ 1.14-1.61 L), both ICS/LABA/LAMA and ICS/LABA in conjunction with bisoprolol showed statistically significant mean falls in amounting to $100 \mathrm{ml} 1.28 \mathrm{~L}$ (95\% CI $1.03-1.53 \mathrm{~L}$ ) and $120 \mathrm{ml}$ respectively $1.26 \mathrm{~L}$ (95\% CI 1.01-1.51 L); equalling and exceeding the MCID of $100 \mathrm{ml}$ respectively. Bisoprolol produced a significant heart reduction of 11 beats $/ \mathrm{min}$ from a baseline of $80 \mathrm{bpm}$ (95\% CI 74-85 bpm) to $69 \mathrm{bpm}$ (95\% CI 64-73 bpm) and $69 \mathrm{bpm}$ (95\% CI 65-73 bpm) for ICS/LABA/LAMA and ICS/LABA respectively. There was no change in salbutamol use, symptom score or oxygen saturation, pre and post bisoprolol, irrespective of triple or dual therapy. In the context of dual or triple therapy, bisoprolol was associated with subtle but significant falls in domiciliary $\mathrm{FEV}_{1}$, which were disconnected from symptoms, reliever use and oxygen saturation.

\section{P278 ASSESSING DIFFERENT VALVED HOLDING CHAMBERS (VHC) WITH FACEMASK FOR DELIVERED MASS TO CARINA WITH INHALED CORTICOSTEROID BY PRESSURISED METERED-DOSE INHALER (PMDI)}

1J Suggett, ${ }^{1} \mathrm{M}$ Nagel, ${ }^{2} \mathrm{~A}$ Bracey. ${ }^{1}$ Trudell Medical International, London, Canada; ${ }^{2}$ Trudell Medical UK, Basingstoke, UK

10.1136/thoraxjnl-2017-210983.420

Introduction and Objectives Laboratory evaluation of VHCfacemask add-ons is ideally undertaken simulating conditions of use. We report a study in which such devices for small child use were evaluated using an anatomical face-model and upper airway commensurate with that of a 4 year old child.
Methods A number of VHCs with facemask ( $\mathrm{n}=3$ devices/ group) were evaluated using an anatomical face-model and upper airway commensurate with that of a 4 year old child. Each VHC was prepared to manufacturer instructions, then evaluated by breathing simulator (ASL5000), mimicking a short coordination delay of $2 \mathrm{~s}$ followed by tidal breathing (tidal volume $(\mathrm{Vt})=155 \mathrm{~mL}, \mathrm{I}: \mathrm{E}$ ratio $=1: 2$, rate $=25$ cycles). The facemask was attached to ADAM-III small child model. The airway was coupled directly to the breathing simulator via a filter below its exit to capture drug particles that would penetrate as far as the carina in a real patient. 5-actuations of fluticasone propionate $(50 \mu \mathrm{g}, \mathrm{FP})$ were delivered at $30 \mathrm{~s}$ intervals. FP recovered from various locations in the aerosol pathway was subsequently assayed by HPLC-UV spectrophotometry.

Results Distribution of recovered FP from each type of VHC is summarised in Table 1.

Conclusions Significantly more FP was delivered to the model 'carina' from the AC Plus VHC with child mask $(\mathrm{p}<0.001)$, the increased mass counterbalanced by decreased retention of medication within the VHC. It is important that clinicians are aware that large differences in delivery efficiency may exist when a facemask is present.

\section{P279 PRIMING OF A NON-CONDUCTING VALVED HOLDING CHAMBER (VHC) MAY RESULT IN INCONSISTENT MEDICATION DELIVERY}

${ }^{1}$ A Bracey, ${ }^{2}$ J Suggett, ${ }^{2} \mathrm{M}$ Nagel. ${ }^{1}$ Trudell Medical UK, Basingstoke, UK; ${ }^{2}$ Trudell Medical International, London, Canada

\subsection{6/thoraxjnl-2017-210983.421}

Introduction and Objectives Priming VHCs with several actuations of medication before use may be an established practice to prepare the spacer before use. However this practice can have a significant influence on subsequent medication delivery. The present study set out to test the hypothesis that priming is not effective, or better than the use of anti-static materials. Methods The following VHCs, each with mouthpiece as patient interface ( $n=5$ devices/group) were evaluated: AeroChamber Plus Flow-Vu Antistatic VHC (AC +FV AVHC); AeroChamber Plus; Volumatic $\cdots$; Able Spacer 2\%; Anti-Static Compact Space Chamber plus ${ }^{*}$. Each VHC was connected via a filter holder to a vacuum source operated at $28.3 \mathrm{~L} / \mathrm{min}$, evaluated with a pMDI (Flovent $125 \mu \mathrm{g}, \mathrm{FP}$ ) and the Emitted Mass of FP $\left(\mathrm{EM}_{\mathrm{FP}}\right)$ determined by HPLC-UV assay. The following sequence of testing was conducted: 1) Test VHC immediately after removal from packaging (no pre-treatment) and evaluate $\mathrm{EM}_{\mathrm{FP}}$ following one actuation. 2) Supply two more actuations into the same $\mathrm{VHC}$ and evaluate $\mathrm{EM}_{\mathrm{FP}}$

Abstract P278 Table 1 FP (mean $\mu \mathrm{g} \pm \mathrm{SD}$ ) recovered from VHCs indicated for small child use, simulating a $2 \mathrm{~s}$ coordination delay followed by tidal breathing

\begin{tabular}{|c|c|c|c|c|c|c|c|c|}
\hline $\begin{array}{l}\text { Retention } \\
\text { Location }\end{array}$ & $\begin{array}{l}\text { AeroChamber Plus Flow- } \\
\mathrm{Vu}\end{array}$ & $\begin{array}{l}\text { Pocket- } \\
\text { Chamber }\end{array}$ & Vortex & $\begin{array}{l}\text { Compact SpaceChamber Anti- } \\
\text { Static }\end{array}$ & $\begin{array}{l}\text { A2A } \\
\text { Spacer }\end{array}$ & Volumatic & $\begin{array}{l}\text { Able* } \\
\text { Spacer2 }\end{array}$ & $\begin{array}{l}\text { Optichamber } \\
\text { Diamond* }\end{array}$ \\
\hline VHC & $17.5 \pm 1.6$ & $36.6 \pm 0.2$ & $\begin{array}{l}39.7 \\
\pm 6.7\end{array}$ & $36.1 \pm 3.6$ & $28.3 \pm 2.8$ & $33.6 \pm 1.9$ & $13.2 \pm 1.6$ & $22.7 \pm 2.7$ \\
\hline Facemask & $1.4 \pm 0.2$ & $1.9 \pm 0.8$ & $1.2 \pm 0.2$ & $0.0 \pm 0.0$ & $0.2 \pm 0.1$ & $0.1 \pm 0.1$ & $0.0 \pm 0.0$ & $3.4 \pm 0.8$ \\
\hline Airway & $1.1 \pm 0.2$ & $0.4 \pm 0.2$ & $0.6 \pm 0.3$ & $0.1 \pm 0.1$ & $0.4 \pm 0.1$ & $0.0 \pm 0.0$ & $0.2 \pm 0.0$ & $0.7 \pm 0.1$ \\
\hline Filter at 'Carina' & $10.1 \pm 1.0$ & $4.0 \pm 1.7$ & $2.7 \pm 1.5$ & $2.1 \pm 0.8$ & $4.1 \pm 0.9$ & $1.5 \pm 0.8$ & $5.1 \pm 0.9$ & $5.1 \pm 0.9$ \\
\hline
\end{tabular}




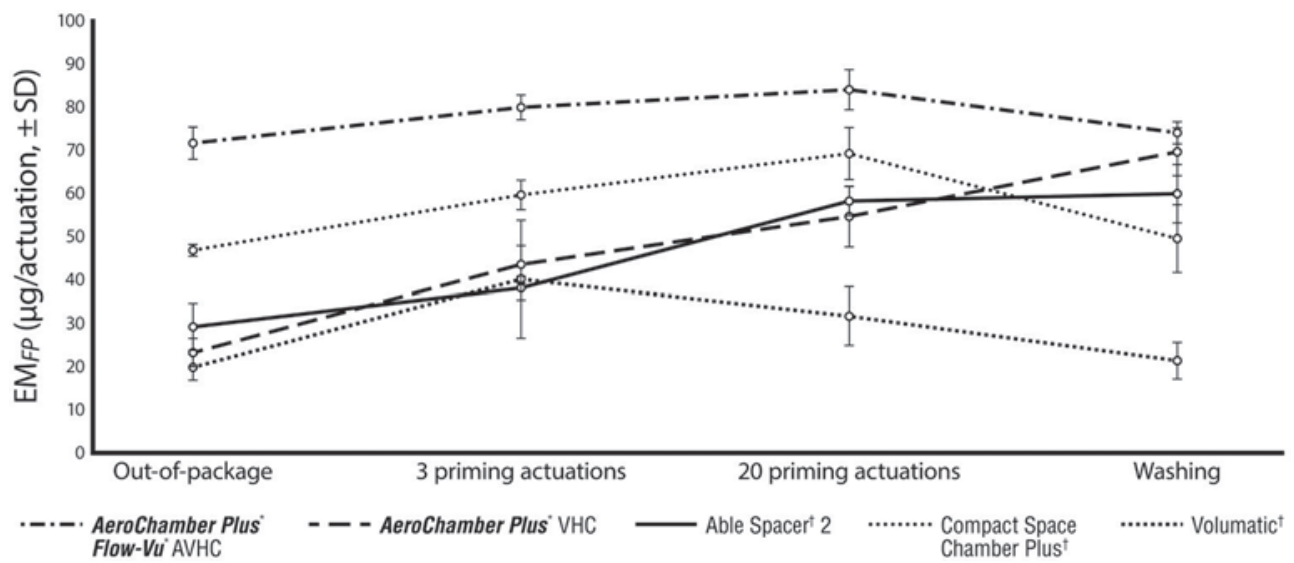

\section{Abstract P279 Figure 1}

(representing 3 actuations of priming).3) Deliver 17 more actuations into the same $\mathrm{VHC}$ and evaluate $\mathrm{EM}_{\mathrm{FP}}$ (representing priming of 20 actuations). 4) Clean VHC, then repeat part (1) (representing pre-conditioning by washing as an alternative to priming).

Results The behaviour of $\mathrm{EM}_{\mathrm{FP}}$ (mean $\pm \mathrm{SD}$ ) with VHC type is summarised in figure 1 .

Conclusions Clinicians should be aware that priming of VHCs Results in inconsistent medication delivery, and is wasteful of medication.

\section{P280 HOW DO WE CHOOSE INHALERS? PATIENT AND PHYSICIAN PERSPECTIVES ON ENVIRONMENTAL, FINANCIAL AND EASE-OF-USE FACTORS}

KL Liew, A Wilkinson. Lister Hospital, East and North Herts NHS Trust, London, UK

\subsection{6/thoraxjnl-2017-210983.422}

Introduction Inhaled therapy is widely used as mainstay treatment in chronic respiratory conditions, however the environmental impact of inhalers is rarely considered when prescribing inhalers. A recent BTS position statement "encourages all prescribers and patients to consider switching pMDIs to non-propellant devices whenever they are likely to be equally effective."(1) Little is known about Patients' or Physicians' perspectives on making such a switch.

Methods A survey was carried out to assess the importance of three factors to consider, if changing to a different but equally effective inhaler - cost, carbon footprint and ease-of-use. Information about the typical costs and carbon footprints of inhalers was provided. 50 patients already using regular inhalers were randomly recruited via Respiratory Clinics at a district general hospital and Pulmonary Rehabilitation sessions. Responses were rated on a 5 -point scale from not important to very important. The same survey was also completed by 50 medical professionals who regularly prescribe inhalers.

Results $80 \%$ of patients surveyed rated the ease-of-use as important or very important consideration when changing inhalers. The 'cost' and 'carbon footprint' of the inhaler were equally important to patients (3.4 out of 5); only $14 \%$ of patients indicated that carbon footprint was of no importance to them.

Abstract P280 Table 1 Comparison of the importance given by patients and physicians to consideration of cost, carbon footprint and ease-ofuse when changing inhalers

\begin{tabular}{|c|c|c|c|c|c|c|c|}
\cline { 3 - 8 } \multicolumn{2}{c|}{} & \multicolumn{2}{c|}{ Inhaler Cost } & \multicolumn{2}{c|}{ Carbon Footprint } & \multicolumn{2}{c|}{ Ease-of-use } \\
\hline $\begin{array}{c}\text { Importance } \\
\text { Ranking }\end{array}$ & Score & Patient & Physician & Patient & Physician & Patient & Physician \\
\hline Not important & 1 & $12 \%$ & $14 \%$ & $14 \%$ & $14 \%$ & $8 \%$ & $0 \%$ \\
\hline Slightly important & 2 & $8 \%$ & $8 \%$ & $8 \%$ & $18 \%$ & $0 \%$ & $2 \%$ \\
\hline $\begin{array}{c}\text { Moderately } \\
\text { important }\end{array}$ & 3 & $32 \%$ & $16 \%$ & $34 \%$ & $22 \%$ & $12 \%$ & $2 \%$ \\
\hline $\begin{array}{c}\text { Important } \\
\text { Imery important }\end{array}$ & 5 & $22 \%$ & $44 \%$ & $16 \%$ & $30 \%$ & $16 \%$ & $12 \%$ \\
\hline $\begin{array}{c}\text { Vertant \& Very } \\
\text { Important }\end{array}$ & $4 \& 5$ & $48 \%$ & $62 \%$ & $44 \%$ & $46 \%$ & $80 \%$ & $84 \%$ \\
\hline $\begin{array}{c}\text { Average (mean } \\
\text { score out of 5) }\end{array}$ & & $26 \%$ & $18 \%$ & $28 \%$ & $16 \%$ & $64 \%$ & $96 \%$ \\
\hline
\end{tabular}

